\title{
NURSES AND INTERNET HEALTH-RELATED INFORMATION: REVIEW ON ACCESS AND UTILITY
}

\author{
MUAYYAD M AHMAD ${ }^{1}$, RUBA MUSALLAM ${ }^{2}$, ABLA HABEEB ALLAH ${ }^{3}$
}

\author{
${ }^{1}$ Clinical Nursing Department, University of Jordan, School of Nursing, Jordan \\ ${ }^{2}$ Directorate of Quality and Inspection. Royal Medical Services, Jordan \\ ${ }^{3}$ Clinical Nursing Department, Princess Muna College of Nursing, Mutah \\ University, Jordan
}

\begin{abstract}
Purpose. To review literature on the nurses' use and access to Internet Health Related Information (HRI).There is relatively little evidence in published literature on barriers, attitudes and how nurses utilize online health-related information.

Methods. Literature search was carried-out on Cumulative Indexes to Nursing and Allied Health Literature (CINAHL), MEDLINE, Google Scholar, Springer and Sage publications. The search timeframe has focused on the outburst of Internet usage between the years 2000 and 2014.

Results. Quality of available websites and databases containing health-related information vary widely in their accuracy, validity and reliability that require nurses to continuously evaluate their relevance.

Conclusion. Emphasis on the necessity for training in the use of information technology is important to the nurses' continuous professional development. Literature showed a strong evidence of the increased access to the Internet by nurses to retrieve information related to clinical practice, which in turns enhance the quality of care and communication among nurses.
\end{abstract}

Keywords: internet, electronic health, health-related information, nursing

\section{Introduction}

The Internet is a global system through which a huge and broad range of recourses and information can be approached. There is a dramatic increase of Internet utilization by users all over the globe; from one billion users in 2005, the number increased to three billion users in 2015 [1]. Electronic health (e-health) is a relatively recent term defined by World Health Organization (2014) as "the transfer of health resources and health care by electronic means" [2]. There are two areas in which e-health is involved: the transfer of Health-Related Information (HRI) to workers in health care facilities and the clients who seek services in such facilities through Internet and telecommunication sources, and the utilization of information technology (IT) and e-commerce to enhance public health services by increasing the knowledge of

Manuscript received: 15.03.2018

Received in revised form: 04.05.2018

Accepted: 05.05.2018

Address for correspondence: mma4jo@yahoo.com health care workers and improving their abilities to use such sources to improve the quality of care [2].

Nurses play an essential part of the health care system as they provide care for patients and families at different levels. Nurses have a pivotal role in delivering high quality care [3]. Although nurses are the largest group of health care providers in hospitals and healthcare centers, there is little evidence in published literature about how they search for online information [4]. Nurses prefer to seek the HRI from colleagues and experts rather than traditional sources [5]. Thus, the need for efficient searching strategies and guidelines that help nurses approach electronic synthesized research for evidence-based health-related information becomes essential [6]. Hospitals equipped with sufficient computers and Internet resources may play a great role in the future by recruiting and retaining clinical staff [7]. Reasons for nurses to seek information online include targets such as improving patients' care and Continuing Professional Development (CPD) [4]. Nurses 
believe that their use of online HRI improves the quality of care [7]. Younger nurses, who hold faculty or director positions, or who have a high academic degree often access online databases more frequently than other nurses $[8,9]$. Nurses with academic education use Internet more easily compared to nurses without academic degrees [10]. Another issue that accentuates the importance of preparing nurses to be Internet literate is the presence of knowledgeable clients referred as "informed patients". Nurses should be prepared to deal with such patients in order to guarantee a safe and conceivable patients' knowledge [11].

Smart phones and personal digital assistants (PDA) are becoming increasingly popular, as they have the ability for downloading health-related applications. These installed applications, so-called "apps", contain vast amount of information that could be used by health-care workers at clinical settings, yet they need to be evaluated for their reliability and relevancy $[12,13,14]$.

Studies that examined the Internet seeking behaviors for nurses are limited. There is insufficient published research about the effect of nursing utilization of online HRI on nursing practice and quality of care. Therefore, the aims for this review were to: 1) Investigate the nurses' use and access of Internet health-related information, 2) Determine reasons behind seeking online information, 3) Recognize how nurses integrate new information technologies in their query for on-line sources, and 4) Identify how nurses embrace available websites addressing health-related information.

\section{Methods}

The literature review process was guided by the review aims. A literature search was performed in the period between 2000 and 2014, using the databases
Cumulative Indexes to Nursing and Allied Health Literature (CINAHL), MEDLINE, PubMed, in addition to Google Scholar. Furthermore, Springer and Sage publications were also searched. Snowballing technique was carried on the reference lists of the studies to obtain more specific and related literature. The search terms used were nurses; Internet; electronic health; health-related information; online, and nursing.

Original research was included if it was published in English that addressed nurses' utility and access to HRI on the Internet. Exclusion criteria: personal opinions and gray literature, which is defined as "The term for information that falls outside the mainstream of published journal and monograph literature, not controlled by commercial publishers, which includes: hard to find studies, reports, or dissertations, conference abstracts or papers governmental or private sector research, clinical trials - ongoing or unpublished and experts and researchers in the field" [15]. Studies that addressed obligatory use of electronic resources by nurses such as patients' hospital databases as part of the health facilities informatics systems, and online webbased nursing programs were also excluded. Additionally, studies that discussed the utilization of online HRI among undergraduate nursing students were also excluded.

The first search resulted in the following citations; 6,595 results were attained from CINAHL, 18,194 from Medline, 6,873 from Sage publications, 8,979 from Springer, and 90,200 from Google scholar. After screening these on title, 75 abstracts were included for further assessment. The authors assessed the abstracts on their relevance for the purpose of the study, which resulted in 44 articles. These were reviewed by all authors and finally 31 articles that met the eligibility criteria were included in this review paper. Figure 1 shows a flow chart of the selection process.

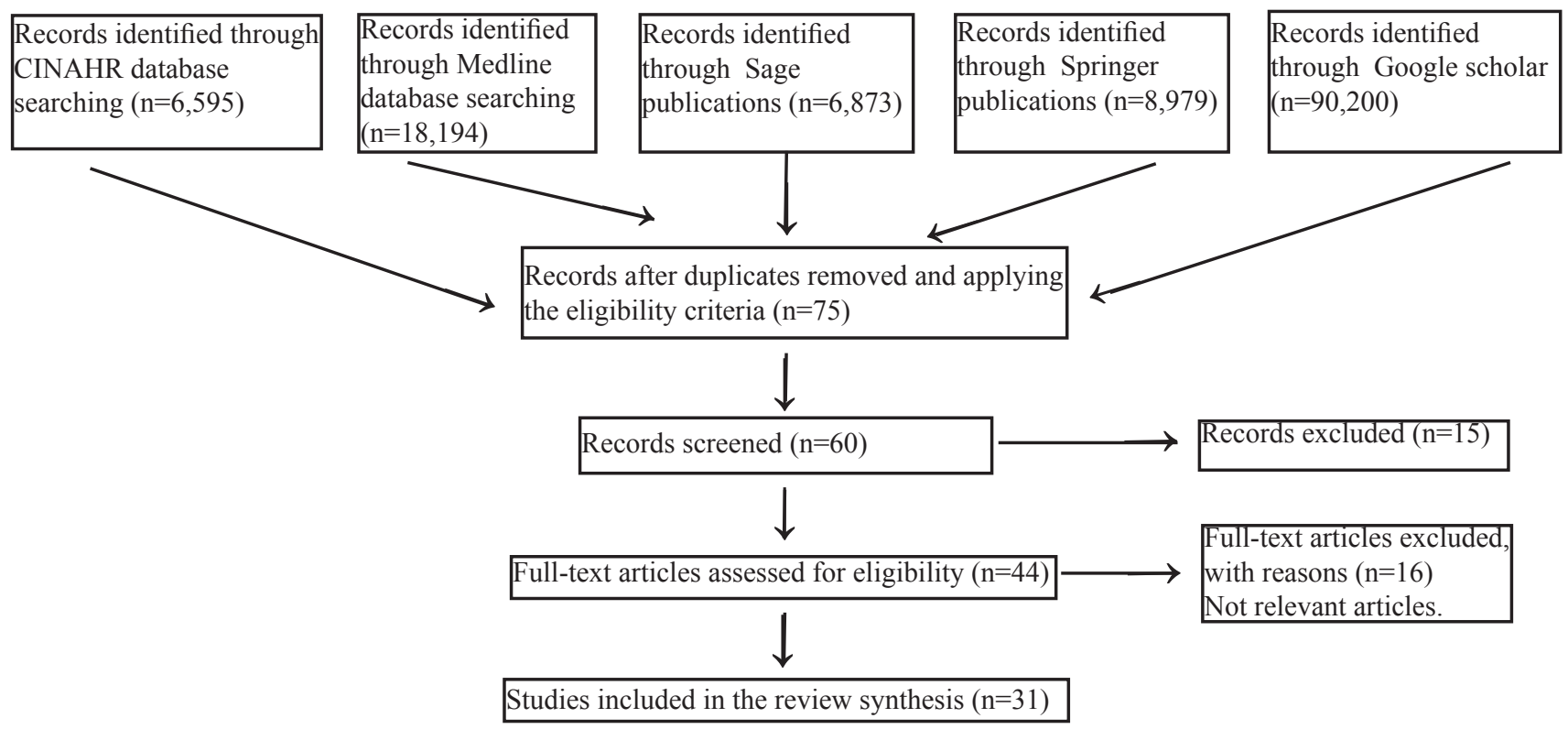

Figure 1. Flow chart for sudies selection. 


\section{Results}

The included studies were heterogeneous with respect to design, sample and setting. Qualitative, and quantitative research designs were included. The samples vary from 4,206 registered nurses (RNs), 23 published articles, 6 databases, and 114 websites for postnatal mental health. Types of included studies in addition to participants are presented in Table 1. Most of the studies were carried in the United Kingdom followed by the United States of America and Canada. A keyword analysis was performed based on the concepts of nurses, Internet, electronic health, and health-related information. Next, a content analysis of the included studies was conducted to systematically identify the main characteristics of the studies on the basis of the terms nurses, Internet, electronic health, and health-related information. The studies were then analyzed and categorized to identify the main themes. Seven main themes were identified: Why do nurses use the Internet? How do nurses search? What are the barriers for Internet use? How can they evaluate available websites? How can the online resources be beneficial for nurses? What are the attitudes among health-care workers using the Internet? And, how do nurses utilized computer-based programs and smart phone's technologies?

\begin{tabular}{|c|c|c|c|c|c|c|}
\hline No. & Author & Title & \begin{tabular}{|l|} 
Country of \\
Publication
\end{tabular} & Design & Sample & Journal \\
\hline 1. & Adams (2009) & $\begin{array}{l}\text { Use of Evidence-Based Practice in } \\
\text { School Nursing: Survey of School } \\
\text { Nurses at a National Conference }\end{array}$ & USA & $\begin{array}{l}\text { Cross-Sectional } \\
\text { Survey Design }\end{array}$ & 247 nurses & $\begin{array}{l}\text { The Journal of School } \\
\text { Nursing }\end{array}$ \\
\hline 2. & Asah (2013) & $\begin{array}{l}\text { Computer usage among nurses in } \\
\text { rural health-care facilities in } \\
\text { South Africa: obstacles and } \\
\text { challenges }\end{array}$ & England & Interview & 40 nurses & $\begin{array}{l}\text { Journal of Nursing } \\
\text { Management }\end{array}$ \\
\hline 3. & $\begin{array}{l}\text { Barnoy et. al } \\
(2011)\end{array}$ & $\begin{array}{l}\text { Self-epistemic authority and nurses' } \\
\text { reactions to medical information that } \\
\text { is retrieved from Internet sites of } \\
\text { different credibility }\end{array}$ & Australia & $\begin{array}{l}\text { Cross-Sectional } \\
\text { Study }\end{array}$ & 101 nurses & $\begin{array}{l}\text { Journal of Nursing \& } \\
\text { Health Sciences }\end{array}$ \\
\hline 4. & Barnoy et.al (2009) & $\begin{array}{l}\text { Nurses Attitudes towards the } \\
\text { Informed Patient }\end{array}$ & Netherlands & $\begin{array}{l}\text { Cross-Sectional } \\
\text { Study }\end{array}$ & 110 nurse & $\begin{array}{l}\text { Studies in Health } \\
\text { Technology and } \\
\text { Informatics }\end{array}$ \\
\hline 5. & Cader et.al (2009) & $\begin{array}{l}\text { Judging nursing information on the } \\
\text { WWW: a theoretical understanding }\end{array}$ & England & $\begin{array}{l}\text { Grounded Theory } \\
\text { Approach }\end{array}$ & 33 nurses & $\begin{array}{l}\text { Journal of Advanced } \\
\text { Nursing. }\end{array}$ \\
\hline 6. & $\begin{array}{l}\text { Chan \& Stieda } \\
(2011)\end{array}$ & $\begin{array}{l}\text { Evaluation of three point-of-care } \\
\text { healthcare } \\
\text { Databases: BMJ Point-of-Care, Clin- } \\
\text { eguide and Nursing Reference Centre }\end{array}$ & England & Descriptive & 46 nurses & $\begin{array}{l}\text { Health information } \\
\text { and libraries journal }\end{array}$ \\
\hline 7. & Doran et.al (2010) & $\begin{array}{l}\text { Supporting Evidence-Based Practice } \\
\text { for Nurses Through Information } \\
\text { Technologies }\end{array}$ & USA & \begin{tabular}{|l|} 
Longitudinal \\
Design, Pre-Post- \\
Test Design \\
\end{tabular} & 488 nurses & $\begin{array}{l}\text { Worldviews on } \\
\text { Evidence-based } \\
\text { Nursing } \\
\end{array}$ \\
\hline 8. & $\begin{array}{l}\text { Fujino \& } \\
\text { Kawamoto (2013) }\end{array}$ & $\begin{array}{l}\text { Effect of Information and } \\
\text { Communication Technology on } \\
\text { Nursing Performance }\end{array}$ & USA & \begin{tabular}{|l|} 
Descriptive \\
Correlational \\
Design \\
\end{tabular} & 556 nurses & $\begin{array}{l}\text { Computers, } \\
\text { Informatics, Nursing }\end{array}$ \\
\hline 9. & Gilmour (2012) & $\begin{array}{l}\text { Nurses' use of online health } \\
\text { information in medical wards }\end{array}$ & England & $\begin{array}{l}\text { Descriptive Cross- } \\
\text { Sectional Survey } \\
\text { Design }\end{array}$ & 293 nurses & $\begin{array}{l}\text { Journal of advanced } \\
\text { nursing }\end{array}$ \\
\hline 10 . & Kurki et.al (2011) & $\begin{array}{l}\text { Usefulness of Internet in adolescent } \\
\text { mental health Outpatient care }\end{array}$ & England & $\begin{array}{l}\text { Explorative } \\
\text { Qualitative Study }\end{array}$ & 12 nurses & $\begin{array}{l}\text { Journal of Psychiatric } \\
\text { and Mental Health } \\
\text { Nursing }\end{array}$ \\
\hline 11. & $\begin{array}{l}\text { Koivunen et al } \\
(2010)\end{array}$ & $\begin{array}{l}\text { Effects of the implementation of the } \\
\text { web-based patient support system on } \\
\text { staff's attitudes towards computers } \\
\text { and IT use: a randomized controlled } \\
\text { trial }\end{array}$ & Sweden & $\begin{array}{l}\text { Randomized } \\
\text { Controlled Trial }\end{array}$ & 149 nurses & $\begin{array}{l}\text { Scandinavian Journal } \\
\text { of Caring Science }\end{array}$ \\
\hline 12. & \begin{tabular}{|l|} 
Koivunen. M., et.al \\
$(2013)$
\end{tabular} & $\begin{array}{l}\text { Occupational Stress and } \\
\text { Implementation of Information } \\
\text { Technology Among Nurses Working } \\
\text { on Acute Psychiatric Wards }\end{array}$ & USA & Descriptive & 146 nurses. & $\begin{array}{l}\text { Perspectives in } \\
\text { Psychiatric care }\end{array}$ \\
\hline 13. & $\begin{array}{l}\text { Kushnir et.al } \\
(2010)\end{array}$ & $\begin{array}{l}\text { Exploration of the link between } \\
\text { speaking English as a foreign } \\
\text { language and Internet use among } \\
\text { nurses in Israel }\end{array}$ & USA & $\begin{array}{l}\text { Descriptive } \\
\text { Correlational } \\
\text { Design }\end{array}$ & 203 nurses & $\begin{array}{l}\text { Journal of Nursing } \\
\text { Informatics }\end{array}$ \\
\hline
\end{tabular}


Review

\begin{tabular}{|c|c|c|c|c|c|c|}
\hline \begin{tabular}{|l|} 
No. \\
\end{tabular} & Author & Title & \begin{tabular}{|l|} 
Country of \\
Publication
\end{tabular} & Design & Sample & Journal \\
\hline 14. & $\begin{array}{l}\text { Lupiáñez- } \\
\text { Villanueva at.al } \\
(2011) \\
\end{array}$ & $\begin{array}{l}\text { The integration of Information and } \\
\text { Communication Technology into } \\
\text { nursing }\end{array}$ & Netherlands & Online Survey & 1170 nurses & $\begin{array}{l}\text { International } \\
\text { Journal of Medical } \\
\text { Informatics }\end{array}$ \\
\hline 15. & $\begin{array}{l}\text { Marshall et.al } \\
(2011)\end{array}$ & $\begin{array}{l}\text { Preferred Information Sources } \\
\text { for Clinical Decision Making: } \\
\text { Critical Care Nurses' Perceptions } \\
\text { of Information Accessibility and } \\
\text { Usefulness }\end{array}$ & USA & Qualitative & 29 nurses & $\begin{array}{l}\text { Worldviews on } \\
\text { evidence-based } \\
\text { nursing }\end{array}$ \\
\hline 16. & $\begin{array}{l}\text { Mokhtar et.al } \\
(2012)\end{array}$ & $\begin{array}{l}\text { Evidence-based practice and related } \\
\text { information literacy skills of nurses } \\
\text { in Singapore: An exploratory case } \\
\text { study }\end{array}$ & USA & $\begin{array}{l}\text { Quantitative } \\
\text { Explorative Study }\end{array}$ & 300 nurses & $\begin{array}{l}\text { Health Informatics } \\
\text { Journal }\end{array}$ \\
\hline 17. & $\begin{array}{l}\text { Moore \& Ayers } \\
(2011)\end{array}$ & $\begin{array}{l}\text { A Review Of Postnatal Mental } \\
\text { Health Websites: Help For Healthcare } \\
\text { Professionals And Patients }\end{array}$ & Austria & Systematic Review & $\begin{array}{l}114 \text { websites for post } \\
\text { natal mental health }\end{array}$ & $\begin{array}{l}\text { Archive of Women's } \\
\text { Mental Health }\end{array}$ \\
\hline 18. & \begin{tabular}{|l|} 
Moore \& \\
Jayewardene \\
$(2014)$ \\
\end{tabular} & $\begin{array}{l}\text { The Use of Smartphones In Clinical } \\
\text { Practice }\end{array}$ & England & $\begin{array}{l}\text { Survey, } \\
\text { Descriptive } \\
\text { Evaluation Study }\end{array}$ & \begin{tabular}{|l|} 
448participants, 82 \\
nurses and 334 doctors
\end{tabular} & Nursing management. \\
\hline 19. & Olsan et.al (2011) & $\begin{array}{l}\text { Finding electronic information for } \\
\text { health policy advocacy: A guide to } \\
\text { improving search results }\end{array}$ & USA & Search Guidelines & $\begin{array}{l}6 \text { databases were } \\
\text { examined }\end{array}$ & $\begin{array}{l}\text { Journal of the } \\
\text { American } \\
\text { Academy of Nurse } \\
\text { Practitioners. } \\
\end{array}$ \\
\hline 20. & Younger (2010) & $\begin{array}{l}\text { Review Article: Internet-based } \\
\text { information-seeking behavior } \\
\text { amongst doctors and nurses: a short } \\
\text { review of the literature }\end{array}$ & England & $\begin{array}{l}\text { Reviewed Paper } \\
\text { From 1995-2009 }\end{array}$ & $\begin{array}{l}23 \text { published articles } \\
\text { were reviewed. }\end{array}$ & $\begin{array}{l}\text { Health information } \\
\text { and libraries journal. }\end{array}$ \\
\hline 21. & Sortedahl (2012) & \begin{tabular}{|l|} 
Effect Of Online Journal Club On \\
Evidence-Based Practice Knowledge, \\
Intent, And Utilization In School \\
Nurses \\
\end{tabular} & USA & $\begin{array}{l}\text { Self-Report Survey } \\
\text { Design }\end{array}$ & 35 school nurses & $\begin{array}{l}\text { Worldviews on } \\
\text { evidence-based } \\
\text { nursing }\end{array}$ \\
\hline 22. & $\begin{array}{l}\text { Tieman \& } \\
\text { Rawlings (2008) }\end{array}$ & $\begin{array}{l}\text { Exploring nurses' attitudes to, and } \\
\text { use of, an online palliative care } \\
\text { resource }\end{array}$ & England & Descriptive & 371 nurses & $\begin{array}{l}\text { International Journal } \\
\text { of palliative nursing }\end{array}$ \\
\hline 23. & Valaitis et.al (2011) & $\begin{array}{l}\text { Online communities of practice } \\
\text { as a communication resource for } \\
\text { community Health nurses working } \\
\text { with homeless persons. }\end{array}$ & USA & Exploratory & 16 nurses & $\begin{array}{l}\text { Journal of Advanced } \\
\text { Nursing }\end{array}$ \\
\hline 24. & $\begin{array}{l}\text { Verhoeven et.al } \\
(2010)\end{array}$ & $\begin{array}{l}\text { How Nurses Seek and Evaluate } \\
\text { Clinical Guidelines on The Internet }\end{array}$ & USA & $\begin{array}{l}\text { Evaluation Of } \\
\text { Nurses Response } \\
\text { Of Using Internet } \\
\text { Guidelines To } \\
\text { Solve Scenarios To } \\
\text { Treat MRSA } \\
\end{array}$ & 20 nurses & $\begin{array}{l}\text { Journal of Advanced } \\
\text { Nursing }\end{array}$ \\
\hline 25. & Wallis (2012) & $\begin{array}{l}\text { Survey Explores Nurses' Use of } \\
\text { E-Health Tools }\end{array}$ & England & $\begin{array}{l}\text { Explanatory } \\
\text { Survey }\end{array}$ & \begin{tabular}{|l|} 
A total of 1,313 nurses, \\
midwives, healthcare \\
support workers \\
and pre-registration \\
students
\end{tabular} & Nursing Management \\
\hline 26. & Weng st.al (2013) & $\begin{array}{l}\text { Information-searching behaviors of } \\
\text { main and allied health professionals: } \\
\text { a nationwide survey in Taiwan } \\
\end{array}$ & England & $\begin{array}{l}\text { Cross-Sectional } \\
\text { Study }\end{array}$ & $\begin{array}{l}\text { 6160participantnurses } \\
(4206) \text { and others } \\
\text { health care providers } \\
\end{array}$ & $\begin{array}{l}\text { Journal of Evaluation } \\
\text { in Clinical Practice. }\end{array}$ \\
\hline 27. & Weng et.al (2013) & $\begin{array}{l}\text { Increasing utilization of Internet- } \\
\text { based resources Following efforts to } \\
\text { promote evidence-based Medicine: a } \\
\text { national study in Taiwan }\end{array}$ & England & $\begin{array}{l}\text { Cross- } \\
\text { Sectional Postal } \\
\text { Questionnaire } \\
\text { Surveys }\end{array}$ & $\begin{array}{l}\text { Physicians and nurses } \\
\text { were enrolled in } 2007 \\
\text { (nurses = 551), 2009 } \\
\text { (nurses=2412), and } \\
2011 \text { (nurses = 3354). }\end{array}$ & $\begin{array}{l}\text { Journal of Medical } \\
\text { Informatics and } \\
\text { Decision Making }\end{array}$ \\
\hline 28. & Yun \& Park (2010) & $\begin{array}{l}\text { Meeting Patient Information Needs: } \\
\text { Consumers' disease information-- } \\
\text { seeking behavior on the Internet in } \\
\text { Korea }\end{array}$ & England & $\begin{array}{l}\text { Online Survey. } \\
\text { Self-Reported } \\
\text { Questionnaire }\end{array}$ & 212 nurses & $\begin{array}{l}\text { International Journal } \\
\text { of Older People } \\
\text { Nursing }\end{array}$ \\
\hline
\end{tabular}




\section{Discussion}

Why do nurses use the Internet?

Evolution of information technology and the increase of various medical sites enabled patients to access health-related information. Acknowledging this fact, many nurses understood the influence of online HRI on patients' health activities and beliefs [16]. Presence of informed patients, who had an easy access to different HRI, urged the nurses to improve their Internet searching skills for different professional and non-professional medical information sites to decrease their discomfort when dealing with patients who utilize the Internet as a source for HRI $[11,17]$. Moreover, acknowledging determinants of health seeking behaviors such as health consciousness, perceived health risk, and Internet health use efficacy was necessary to help the nurses to design the appropriate programs and assuring best information quality $[18,19]$. The nurses' role as the provider of information is shifted to being a director and consultant for patients to assess their retrieved HRI. As there is a sufficient on-line access for staff, this improved the patients' access to trustful on-line HRI during their hospitalization period; therefore, nurses used the Internet to help the patients gain the benefit of online education material about self-care management [7]. A survey conducted in Spain, labeled nurses who value Internet as "integrated-nurses" in a way that they integrate Information and Communication Technology (ICT) in their work to practice research activities with a belief that health information available on the Internet was very relevant to their work. In addition, the national information sources were used as a communication tool by nurses and patients [16]. A randomized control study conducted by Koivunen et al. (2010) acknowledged that nurses had positive attitudes towards using ICT [20]. One trigger to seek on-line health information for nurses was self-learning. Other stimuli included clinical practice, position development, academic assignment, preparing instructions, research, accreditation and insurance issues [9].

\section{How do nurses search?}

Accessing limited websites and using few search words in addition to visiting only convenient sites, indicated unplanned searches [21]. Nurses judge information as complete and relevant if it helps them to decide for practice and/or if it adds to their knowledge more than what is considered by experts. This might affect their patients by utilizing wrong information and creates a potentially harmful clinical situation [21]. Nurses who had high self-epistemic authority had more positive attitudes toward health information retrieved from credible sites such as Medline and responded more positively to it. However, nurses with low self-epistemic authority felt more comfortable when dealing with health information retrieved from popular sites because language is easier to understand [18]. In a study by Weng et al. (2013) they concluded that nurses prefer to use web portals (such as
Google and Yahoo) as an information source [9].

\section{Barriers for Internet use}

The main barriers reported by nurses related to seeking Internet information are being too busy to have enough time to search the web, difficulties in searching procedure because of skills deficiency, and lack of access [4]. A limited use of electronic information resources by nurses was due to inability of the nurses to translate their desired information into a query that can be understood by the retrieval system [22]. Sometimes, even ICT skilled nurses have a barrier to approaching on-line health information because of trouble accessing passwords [5]. Another barrier mentioned by Younger (2010) is the unawareness of nurses of the library as a reliable and efficient place for seeking online information [4]. Despite the availability of the on-line information access for nurses at work and at home, lack of time is still considered a major barrier [7]. On the contrary, availability of direct information in a relatively very short time makes on-line medical information more attractive and practical for nurses [8]. They considered colleagues as a source of information to be more efficient than the printed or electronic based information sources because this way is more accessible and takes less time; in addition, it gives them an opportunity to discuss the clinical situation which leads to a more confident clinical decision [5]. Lack of advanced ICT skills made the nurses practice basic information-seeking skills. Moreover, nurses relied more on their implicit and traditional knowledge during the process of searching and evaluation of retrieved clinical guidelines [21]. As long as the guidelines matched the nurses' tacit knowledge, they considered them trustworthy, relevant, and comprehensive; but they would deny the retrieved information if it opposes what they already believe in and practice. This is considered risky because it might result in an inadequate and unsafe practice. Lack of ICT infrastructure, little technical and nursing management support, and improper physical location of computers in the health-care settings are acknowledged as main barriers of computer handling by nurses, especially in rural hospitals [23]. Furthermore, English language is another barrier to get access to the Internet medical information, especially for nurses whom their native language is not English $[9,10]$. This language issue may affect the nurses' abilities and courage to follow evidence-based practices in the nursing profession [10].

\section{Evaluation of the available websites}

Most sites need to be evaluated in regard to the accuracy of information and updating its content with relevant evidence-based data. Moore and Ayers (2011) conducted a systematic review to evaluate 114 postnatal mental health websites, which provided information and help for patients and health care professionals [24]. The material and information in these websites were incomplete and there was limited access to helpful resources. With the rapid growth in the Internet, it is now easy to retrieve information without the need to go back 
for traditional sources [25]. It is important before adapting such information by the nurses to decide its relevance to the profession; once this is established, nurses need to assure the reliability of the information. This process of reliability testing was the aim of the study that was conducted by Cader et al. (2009) in which a grounded theory approach was used [25]. They found that nurses used different levels of intellectual skill such as intuition, quasi-rational and analytical modes of cognition and World Wide Web information cues. Time availability and nurses' critical skills were influencing factors in their judgment process. Although this study identified cognitive judgment process of testing, the sample size of 20 nurses may not be sufficient to draw conclusions. More investigations with different designs and larger samples are needed to evaluate this process on a wider base. Not only the nurses' cognitive process was evaluated in the literature, but also some of the relevant databases were evaluated for their contents and usefulness as sources for information approached and utilized by nurses at the clinical settings. Chan and Stieda (2011) found that the choice of databases depends on the user's preferences, and most of the users, which are nurses in this case, found databases easy to use [26].

\section{nurses?}

How can online resources be beneficial for

With the increased effectiveness of the Internet for dissemination of information to facilitate application of Evidence-Based Practice (EBP) in the clinical settings, some specialties of nursing profession in communities of practice found a way to utilize the Internet in their practice. School health nurses used the online journal clubs to increase the utilization of EBP application, and researchers benefited from this experience to have a direct communication with the target consumers of their studies [27]. In a crosssectional survey conducted by Adams regarding the use of EBP by school nursing, $65 \%$ of respondents preferred to use the Internet rather than text books [28]. Furthermore, $73 \%$ of the respondents found it beneficial for them to access computer-based distance learning regarding EBP for which higher computer abilities and access to computers were associated with use of the Internet as a source for information but not to traditional sources such as seminars attending or continuing education programs. Valaitis et al. (2011) explored the opinions of the community health nurses about sharing on-line knowledge, stories and concerns; the participants said that it was important to have such communities to limit their feelings of isolation and to have connections with their colleagues to share their experiences [29]. Some nursing specialty that showed promising benefits from using the Internet to improve the quality of care is mental health nurses. Kurki et al. (2011) explored the opinions of 12 Finnish mental health nurses in a study regarding the use of the Internet to communicate with their depressed adolescent patients; nurses stated that the Internet has promising benefits for psychiatric nursing care, and the use of the Internet would improve the interaction between nurses and adolescents [30]. However, lack of computer training and limited knowledge for the use of the Internet among adolescents with depression on outpatient bases form barriers for Internet use among nurses. Dickerson et al. (2005) in a phenomenology study, explored the experiences of 20 oncology nurses to provide in-depth understanding of the issues encountered in the use of the Internet in their clinical practice [31]. Nurses highlighted the importance of the Internet for accessing and retrieving information concerning oncology by them and by their patients, which enhanced the nurse-patient relationship. Participants identified that computer skills and institutional environment either encouraged or limited the nurses' utilization for e-health-related knowledge [31].

\section{Nurses' attitudes for using the Internet}

Nurses' attitudes, behaviors, work environment and abilities are determinant aspects for accessing the Internet to search for health-related information. Many studies addressed issues such as factors that influencing health care professionals to access and utilize HRI to improve the quality of care. Koivunen et al., described the relation of occupational stress and nurses' attitudes toward ICT in acute psychiatric wards [32]. Nurses who have positive attitudes toward Internet showed less stress and more job satisfaction than nurses with neutral attitude. Therefore, these attitudes should be supported to increase the use of ICT in daily nursing work to decrease stress and increase satisfaction. The role of nurse managers and leaders was highlighted as an important factor to overcome limitations in using ICT. Nurse Managers and leaders should be computer literate to ensure that nurses have adequate ICT access for competent e-health development [33]. They should value the need for nurses to improve their intellectual features of practice as much as their physical aspects of the practice. Nurse Managers also have to increase their awareness and efforts to provide an accessible computer and Internet terminals available for all working nurses [34].

Utility of computer-based programs and smart phones technologies by nurses

Nurses' computer skills and research evaluating abilities are issues addressed by Mokhtar et al. (2012) in Singapore where they examined nurses' abilities to retrieve, evaluate, judge and implement research findings from computer-based sources [35]. Nurses preferred printed and humanitarian source of information compared to electronic sources.

Weng et al. (2013a) reported a significant increase in the use of four Internet-based resources (web portals, online databases, electronic journals and e-books) across the three survey years among physicians and nurses [8]. The results highlighted the significance of the Internet as a prominent foundation of medical information for main healthcare specialists. Doran et al. (2010) examined the use of PDA to access information resources by nurses, and the relationship 
between PDA or tablet-supported information resources and outcomes [14]. The study revealed that the use of ICT as smart phones for the provision of information lead to improvement in nurses' research values and awareness, and in the presentation and accessibility of research evidence. However, PDA users demonstrated higher improvements in the quality of care and job satisfaction than tablet users [14].

\section{Implications for nursing and health policy}

Research shows strong evidence of increased Internet access by health care professionals to retrieve information related to clinical practice. Health-related web sites, journals, and data-bases are sources for evidencebased knowledge that were implemented to improve the nurses' quality of care, and enhance communication among various health specialties $[8,9,31]$. Librarians and senior nurses in administrative positions have an important role as a key source for the availability of online information at hospitals' libraries. They are able to provide a credible and easy access for applicable health-related data bases for nurses, physicians, and other health care providers [4]. An attentive evaluation of the content of the websites to ensure the accuracy of the accessed information is needed to determine which site to use in terms of ease of access, complete content and up-to-date information $[23,25]$. Nurses need to be proficient in computer and ICT to differentiate between credible and non-credible online HRI. This would improve their practice, and help their patients to utilize information in a proper way. It is essential to train nurses to be efficient users of various professional and popular medical information sites, and to be able to utilize evidencebased practice and different clinical guidelines. Nurses found many ways to use the Internet to share information, accessing up-to-date evidence based knowledge with their peer groups from the same specialties and to find new treatment and follow up methodologies with their patients and target population [27-31,36]. Owing high ICT practical skills also improve nurses' level of interpersonal relations, communication, and professional growth [37].

Literature emphasized inclusion of information technology skills and using professional health related databases to retrieve trusted medical information on nursing curricula. This is vital since early exposure of nursing students to ICT could increase positive attitudes and self-confidence toward computer usage. Education of informatics should be provided to all nurses regardless their age, their experience, or their level of education. This kind of education should improve ICT skills and nurses' abilities to retrieve useful and effective information, either by using static computers, personal laptops, or smart phones [37,38].

\section{Conclusion}

Literature showed a strong evidence of the increased access to the Internet by nurses to retrieve information that are related to clinical practice. Nurses access health related web sites like journals and health data bases to expand knowledge that improve their clinical judgment and quality of care. Nurses should be trained to be efficient users of various professional and popular medical information sites to be able to utilize the evidence-based knowledge and different clinical guidelines. Additionally, nurses should be able to guide their patients to access credible online health-related information. Senior nurses in administrative positions have an important role as a key source for the availability of credible and easy accessed health related databases at hospital libraries. There is a strong need for the existence of contextual relevant, dynamic, and well organized Internet material that fit particular needs of nurses. An attentive evaluation of the content of the websites to insure the accuracy of the accessed information is needed to determine which site to use in terms of ease of access, complete content and up to date information. Literature emphasized on the importance of the inclusion of ICT skills and using professional health related databases to retrieve trustful medical information on nursing curricula. Early exposure of nursing students to ICT could increase the positive attitudes and self-confidence toward computer usage. Owing high ICT practical skills improved the nurses' abilities to retrieve useful and effective information either by using static computers, personal laptops, or their own smart phones which in turn better enhanced nurses' level of interpersonal relations and professional growth.

\section{Limitations}

This review encompasses difficulties because there are, as was pointed out in previous reviews, various terms used in included studies in addition to a lack of consistency of designs and methodologies, and there was a an obvious discrepancy in conducting studies addressing this issue around the world, so it was difficult to find a bulk research to make redundant knowledge about it.

\section{Acknowledgements}

The authors acknowledge the partial funding from the University of Jordan.

\section{References}

1. Internet Society, 2017. Open and Sustainable Access for All. [Online] Available from: https://cdn.prod.internetsociety.org/wpcontent/uploads/2017/08/IS_ExSummary_30may.pdf.

2. WHO, 2014. Definition of electronic health. [Online] Available from: http://www.euro.who.int/en/health-topics/Health-systems/ e-health.

3. Cipriano PF. The future of nursing and health IT: the quality elixir. Nurs Econ. 2011;29(5):286-289, 282.

4. Younger P. Internet-based information-seeking behavior amongst doctors and nurses: a short review of the literature. Health Info Libr J. 2010;27(1):2-10.

5. MarshallAP, West SH, Aitken LM. Preferred information sources for clinical decision making: critical care nurses' perceptions of information accessibility and usefulness. Worldviews Evid Based Nurs. 2011;8(4):224-235.

6. Olsan TH, Bianchi C, White P, Glessner T, Mapstone PL. Finding electronic information for health policy advocacy: 
a guide to improving search results. J Am Acad Nurse Pract. 2011;23(12):648-658.

7. Gilmour JA, Huntington A, Broadbent R, Strong A, Hawkins M. Nurses' use of online health information in medical wards. J Adv Nurs. 2012;68(6):1349-1358.

8. Weng YH, Kuo KN, Yang CY, Lo HL, Shih YH, Chen C, et al. Increasing utilization of Internet-based resources following efforts to promote evidence-based medicine: a national study in Taiwan. BMC Med Inform Decis Mak. 2013 Jan 7;13:4. doi: 10.1186/1472-6947-13-4.

9. Weng YH, Kuo KN, Yang CY, Lo HL, Shih YH, Chiu YW. Information-searching behaviors of main and allied health professionals: a nationwide survey in Taiwan. J Eval Clin Pract. 2013;19(5):902-908.

10. Kushnir T, Bachner Y, Barnoy S. Exploration of the link between speaking English as a foreign language and Internet use among nurses in Israel. Online Journal of Nursing Informatics. 2010;14(3):1-15.

11. Barnoy S, Volfin-Pruss D, Ehrenfeld M, Kushnir T. Nurses attitudes towards the informed patient. Stud Health Technol Inform. 2009;14(6):396-399.

12. Kamerow D. Regulating medical apps: which ones and how much?. BMJ. 2013 Oct 8;347:f6009. doi: 10.1136/bmj.f6009.

13. Moors S, Anderson J, Cox S. Pros and cons of using apps in clinical practice. Nurs Manag (Harrow). 2012;19(17):14-17.

14. Doran DM, Haynes RB, Kushniruk A, Straus S, Grimshaw J, Hall LM, et al. Supporting evidence-based practice for nurses through information technologies. Worldviews Evid Based Nurs. 2010;7(1):4-15.

15. US National Library of Medicine. Collection Development Manual. Grey literature (2015). Available from:https://www.nlm. nih.gov/tsd/acquisitions/cdm/formats26.html.

16. Lupiáñez-Villanueva F, Hardey M, Torrent J, Ficapal P. The integration of Information and Communication Technology into nursing. Int J Med Inform. 2011;80(2):133-140.

17. Ahmad M, Alzayyat A, Al-Gamal E. The factor structure of the internet addiction tool with university students in Jordan. Issues Ment Health Nurs. 2015;36(9):725-731.

18. Barnoy S, Volfin-Pruss D, Ehrenfeld M, Kushnir T. Selfepistemic authority and nurses' reactions to medical information that is retrieved from Internet sites of different credibility. Nurs Health Sci. 2011;13(3):366-370.

19. Yun EK, Park HA. Consumers' disease information-seeking behavior on the Internet in Korea. J Clin Nurs. 2010;19(1920):2860-2868.

20. Koivunen M, Välimäki M, Patel A, Knapp M, Hätönen H, Kuosmanen L, et al. (2010). Effects of the implementation of the web-based patient support system on staff's attitudes towards computers and IT use: a randomised controlled trial. Scand J Caring Sci. 2010;24(3):592-599.

21. Verhoeven F, Steehouder MF, Hendrix RM, van GemertPijnen JE. How nurses seek and evaluate clinical guidelines on the Internet. J Adv Nurs. 2010;66(1):114-127.
22. Clarke MA, Belden JL, Koopman RJ, Steege LM, Moore JL, Canfield SM, et al.Information needs and information-seeking behaviour analysis of primary care physicians and nurses: a literature review. Health Info Libr J. 2013;30(3):178-190.

23. Asah F. Computer usage among nurses in rural health-care facilities in South Africa: obstacles and challenges. J Nurs Manag. 2013;21(3):499-510.

24. Moore D, Ayers S. A review of postnatal mental health websites: help for healthcare professionals and patients. Arch Womens Ment Health. 2011;14(6):443-452.

25. Cader R, Campbell S, Watson D. Judging nursing information on the WWW: a theoretical understanding. J Adv Nurs. 2009;65(9):1916-1925.

26. Chan R, Stieda V. Evaluation of three point-of-care healthcare databases: BMJ Point of-Care, Clin-eguide and Nursing Reference Centre. Health Info Libr J. 2011;28(1):50-58.

27. Sortedahl C. Effect of online journal club on evidence-based practice knowledge, intent, and utilization in school nurses. Worldviews Evid Based Nurs. 2012;9(2):117-125.

28. Adams S. Use of evidence-based practice in school nursing: survey of school nurses at a national conference. J Sch Nurs. 2009;25(4):302-313.

29. Valaitis RK, Akhtar-Danesh N, Brooks F, Binks S, Semogas D. Online communities of practice as a communication resource for community health nurses working with homeless persons. J Adv Nurs. 2011;67(6):1273-1284.

30. Kurki M, Koivunen M, Anttila M, Hätönen H, Välimäki M. Usefulness of internet in adolescent mental health outpatient care. J Psychiatr Ment Health Nurs. 2011;18(3):265-273.

31. Dickerson S, Boehmke M, Ogle C, Brown JK. Out of necessity: oncology nurses' experiences integrating the internet into practice. Oncol Nurs Forum. 2005;32(2):355-362.

32. Koivunen M1, Kontio R, Pitkänen A, Katajisto J, Välimäki M. Occupational stress and implementation of information technology among nurses working on acute psychiatric wards. Perspect Psychiatr Care. 2013; 49(1):41-49.

33. Wallis A. Survey explores nurses' use of e-health tools. Nurs Manag (Harrow). 2012;18(10):14-19.

34. Estabrooks C, O'Leary K, Ricker KL, Humphrey CK. The Internet and access to evidence: how are nurses positioned?. $\mathrm{J} \mathrm{Adv}$ Nurs. 2003;42(1):73-81.

35. Mokhtar IA, Majid S, Foo S, Zhang X, Theng YL, Chang YK, et al. Evidence-based practice and related information literacy skills of nurses in Singapore: an exploratory case study. Health Informatics J. 2012;8(1):12-25.

36. Horgan A, Sweeney J. Young students' use of the Internet for mental health information and support. J Psychiatr Ment Health Nurs. 2010;17(2):117-123.

37. Fujino Y, Kawamoto R. Effect of information and communication technology on nursing performance. Comput Inform Nurs. 2013;31(5):244-250.

38. Moore S, Jayewardene D. The use of smartphones in clinical practice. Nurs Manag (Harrow). 2014;21(4):18-22. 